\title{
Hepatic protein synthesis in the sheep: effect of intake as monitored by use of stable-isotope-labelled glycine, leucine and phenylalanine
}

\author{
BY A. CONNELL, A. G. CALDER, S. E. ANDERSON AND G. E. LOBLEY* \\ Rowett Research Institute, Bucksburn, Aberdeen AB21 9SB
}

(Received 2 January 1996 - Revised 6 June 1996 - Accepted 19 June 1996)

\begin{abstract}
Rates of protein synthesis for the liver, plasma albumin and total plasma protein were quantified in sheep either offered a supra-maintenance intake or fasted for $3 \mathrm{~d}$. The technique of continuous infusion over a $12 \mathrm{~h}$ period was employed with the simultaneous infusion of $\left[1-{ }^{13} \mathrm{C}\right] \mathrm{glycine}$, $\left[1{ }^{13} \mathrm{C}\right]$ leucine and $\left[{ }^{2} \mathbf{H}_{5}\right]$ phenylalanine. Blood and plasma samples were removed at timed intervals from the hepatic portal and hepatic veins plus the aorta. Enrichments of the free amino acids (AA) were determined in all blood and plasma samples as was the protein-bound $\mathbf{A A}$ in an apolipoprotein B100 extract. Protein-bound phenylalanine enrichments were also measured in albumin and total protein from plasma plus samples from liver biopsies. The apolipoprotein B100 enrichments agreed well with those of the free $A A$ in hepatic (and hepatic portal) plasma but were lower than for arterial free $A A$ and greater than liver homogenate free $A A$. This adds support to the concept that export proteins may preferentially use AA directly from extracellular sources. Intake had no significant effect on constitutive liver protein synthesis and the values agreed well with those obtained by other isotopic approaches. There were, however, significant declines, based on hepatic venous free phenylalanine enrichment, at the lower intake in both the fractional $(3.4 \mathrm{v} .4 .7 \%$ per $\mathrm{d} ; P=0.024)$ and absolute $(2.4 v .4 .2 \mathrm{~g} / \mathrm{d} ; P=0 \cdot 011)$ synthesis rates of albumin, which matched the estimated decrease in total plasma albumin content $(52$ v. $67 \mathrm{~g}, P<0 \cdot 01)$. In contrast, there was a smaller reduction in total plasma protein mass $(145 v .151 \mathrm{~g}, P=0.035)$ with no observed significant difference in kinetic parameters. Albumin synthesis was calculated to account for a maximum of $17 \%$ of total liver protein synthesis in the fed condition and this may fall to $8 \%$ during moderate fasts.
\end{abstract}

Liver: Protein synthesis: Stable isotopes: Sheep

The mammalian liver is a key organ in regulation of both energy and protein metabolism (Reynolds et al. 1991) and, as such, needs to respond to both nutritional and physiological events. Among the observed metabolic adaptations are the synthesis of specific enzymes (e.g. Schirmer \& Harper, 1970) as well as the large changes in hepatic protein mass which can occur in response to alterations in intake (Burrin et al. 1990). There is a continued debate as to whether these changes in mass arise primarily from alterations in protein degradation (Mortimore \& Surmacz, 1984) or synthesis (Pell et al. 1986), a controversy complicated by the production of both constitutive and export (plasma) proteins within the tissue, the turnover of which may be regulated differently. The liver is also the major site of amino acid (AA) catabolism and considerable quantities of absorbed AA are extracted from the portal vein during passage across the hepatic bed in both ruminants and nonruminants (e.g. Heitmann \& Bergman, 1980; Rérat et al. 1992; Lobley et al. 1996). This can result in insufficient quantities of some essential free AA entering the systemic cir-

$$
\text { *For reprints. }
$$


culation to support the observed whole-body protein gain (Lobley et al. 1996). One explanation for such a phenomenon is that the AA are made available from the liver in other forms, notably protein or peptides. Thus, plasma proteins synthesized within the liver may, amongst other biological roles, provide a reservoir of AA for peripheral tissues (Elwyn $e t$ al. 1968; Chalmers et al. 1982).

The current study using young sheep as the model was designed, therefore, to address two questions. First, in response to changes in nutrition do either hepatic constitutive and/ or export protein synthesis alter? Second, are the quantities of plasma proteins (notably albumin) exported from the liver sufficient, in conjunction with free AA availability, to support tissue protein gain?

Two main isotopic approaches are available to provide quantitative responses to these questions. First is the large, or 'flood', dose procedure, which has been used to monitor acute responses in plasma albumin synthesis to feeding in human subjects (Hunter et al. 1995) but this technique has been challenged recently on a variety of grounds (see Smith et al. 1992; Garlick et al. 1994; Rennie et al. 1994). The second method is based on steadystate kinetics and continuous infusion of tracer or, in the case of stable isotopes, 'quasitracer' quantities of AA. In this approach the various free AA pools (e.g. blood, plasma, extracellular and intracellular compartments) achieve different isotopic activities and doubt then exists as to which, if any, of these best represents the true precursor(s) for protein synthesis. This becomes particularly problematical when constitutive and export proteins may be synthesized within different cellular compartments. One option is to select products of hepatic origin which have sufficiently short half-lives that their isotopic activities reach an asymptote within the infusion time-span. Two such possibilities are hippuric acid, synthesized from benzoic acid and glycine (Le Floc'h et al. 1995), and the secreted protein apolipoprotein B100, which forms part of the VLDL complex (e.g. Reeds et al. 1992; Motil et al. 1994). These provide intracellular and export products respectively, which can be compared with the isotopic activities of free AA in various body pools and decisions made as to which best represent the precursor(s) for constitutive and export protein synthesis. These options were examined in the current study by use of infusion of three labelled AA (glycine, leucine and phenylalanine) in animals prepared with hepatic arterio-venous catheters where, combined with excision of small liver biopsies, a wide range of precursor pools could be compared.

\section{MATERIALS AND METHODS}

\section{Preliminary study}

The kinetics and methods for isolation of apolipoprotein B100 were examined in three Suffolk cross wether lambs ( $52 \mathrm{~kg}$ average live weight) housed in metabolism cages and maintained for several weeks before the study on $1200 \mathrm{~g}$ grass pellets/d (10.5 MJ metabolizable energy/kg DM; $31.8 \mathrm{~g} \mathrm{~N} / \mathrm{kg}$ DM; DM 0.91), supplied as twenty-four $1 \mathrm{~h}$ portions from automated feeders. Each animal was previously prepared with indwelling catheters in the aorta, hepatic portal and hepatic veins (Lobley et al. 1995) and an additional temporary polyvinyl chloride catheter (Harris et al. 1992) in an external jugular vein. All catheters were maintained patent by use of citrate $(0.12 \mathrm{M})$-glucose $(0.13 \mathrm{M})$; care was taken that heparin was excluded from the system for at least $7 \mathrm{~d}$ as this may alter distributions between the various lipoprotein fractions.

Animals were continuously infused with $\left[1{ }^{13} \mathrm{C}\right]$ leucine $(20 \mathrm{mM} ; 0.4 \mathrm{mmol} / \mathrm{h})$ dissolved in sterile $0.15 \mathrm{M}-\mathrm{NaCl}$ into the jugular vein for $12 \mathrm{~h}$. Blood samples $(10 \mathrm{ml})$ were removed from the other catheters at $2 \mathrm{~h}$ intervals, starting $4 \mathrm{~h}$ after the start of infusion, and 
collected into $0.25 \mathrm{ml} 0.5 \mathrm{M}$-disodium EDTA. Plasma was separated by centrifugation at $1000 \mathrm{~g}$ for $15 \mathrm{~min}$ and either used immediately for preparation of apolipoprotein B100, or subfractions stored for later analysis of free leucine enrichment.

\section{Main study: animals, diet and design}

Four Suffolk cross wether lambs (52-60 kg live weight; 15-18 months old) prepared with indwelling catheters in the aorta, hepatic portal, hepatic and mesenteric (two) veins (Lobley et al. 1995) and used in a previous study (Milano, 1994) were housed in metabolism cages and offered $1200 \mathrm{~g}$ grass pellets/d supplied as twenty-four $1 \mathrm{~h}$ portions from automated feeders. A temporary polyvinyl chloride catheter was inserted in the jugular vein, as in the preliminary study, and all catheters were filled with citrate-glucose solution.

Each animal was studied twice, once in the fed condition and once after $3 \mathrm{~d}$ of food withdrawal, with the order of dietary regimens alternated between sheep. A 3-week interval was left between the measurements. A mixture of stable-isotope-labelled AA, $\left[1-{ }^{13} \mathrm{C}\right]$ glycine $(43 \mathrm{mM}, 0.8 \mathrm{mmol} / \mathrm{h}),\left[1{ }^{13} \mathrm{C}\right]$ leucine $(33 \mathrm{mM}, 0.65 \mathrm{mmol} / \mathrm{h})$ and [ring- ${ }^{2} \mathrm{H}_{5}$ ]phenylalanine $(12 \mathrm{mM}, 0.24 \mathrm{mmol} / \mathrm{h})$, dissolved in sterile $0.15 \mathrm{M}-\mathrm{NaCl}$ was infused on each occasion for $12 \mathrm{~h}$.

The choice of AA was determined by the following factors. Glycine allows hepatic intracellular glycine enrichment to be determined indirectly and non-invasively from urinary hippurate. Leucine is the most commonly used tracer for whole-body irreversible loss rates (ILR) in human and farm animals studies and, thus, provides a good comparative base. Furthermore, the easily accessible oxo-acid in plasma is often considered to be representative of intracellular leucine enrichments. In ruminants, hepatic extraction of absorbed leucine is low (e.g. Heitmann \& Bergman, 1980) and thus extracellular sources of the AA make a smaller contribution to the intracellular free AA pool. In contrast, phenylalanine has a high fractional extraction by the liver and may limit peripheral tissue anabolism. In addition, a rapid specific gas-chromatography-mass-spectrometry (GCMS) technique was available to measure the protein-bound $\left[{ }^{2} \mathrm{H}_{5}\right]$ phenylalanine which obviated the need for laborious isolation and isotope-ratio-mass-spectrometer methods. For this reason, other than for apolipoprotein B100, protein-bound enrichments were only quantified for phenylalanine incorporation.

Blood samples $(5 \mathrm{ml})$ were taken from the aorta at $2 \mathrm{~h}$ intervals starting from $6 \mathrm{~h}$ after the start of the infusion. These were used to examine the effectiveness of pseudo-plateau isotopic steady-state for ILR of the three AA and provide samples for measurement of packed cell volume (PCV) plus concentration and isotopic enrichment of plasma total protein and albumin. Samples were also withdrawn from the aorta $(15 \mathrm{ml})$, hepatic portal (5 $\mathrm{ml}$ ) and hepatic $(5 \mathrm{ml})$ veins at $0.5 \mathrm{~h}$ intervals between 11 and $12 \mathrm{~h}$ of infusion and these were used to provide information on dilutions of blood and plasma free AA enrichments across the liver and for measurement of plasma apolipoprotein B100 enrichment (arterial sample only).

Animals were also harnessed to allow collections of urine, by aspiration, for subsequent analysis of hippurate enrichment. Urine samples were taken between 8-10 h and 10-12 $\mathrm{h}$ of infusion. After the last blood sample was taken, but while the infusion continued, a liver biopsy $(250 \mathrm{mg}$ ) was taken by laparotomy techniques under local anaesthesia. On the day before each infusion samples of blood, plasma and urine were collected for background determinations (natural abundance and/or residual enrichment) for the various fractions. 


\section{Analyses}

Total protein and albumin in plasma were determined by automated methods based on the use of the Biuret reagent (Gornall et al. 1949) and reaction with bromocresol purple (Pinnel \& Northam, 1978; Haythorn \& Sheenan, 1979).

Isolation of apolipoprotein B100. To $5 \mathrm{ml}$ plasma was added $25 \mu \mathrm{l}$ sodium azide (100 $\mathrm{g} / \mathrm{l}), 12.5 \mu \mathrm{l} 0.5 \mathrm{M}$-disodium EDTA and $12.5 \mu \mathrm{l} \mathrm{NaI}(360 \mathrm{~g} / \mathrm{l})$ and the solution $(\rho 1.34)$ gently mixed. This was then carefully inserted beneath $3 \mathrm{ml}$ of overlay solution $(89 \mathrm{~g} \mathrm{NaCl} /$ 1 containing $2.5 \mathrm{ml} / 10.5 \mathrm{M}$-disodium EDTA; $\rho$ 1.006) in a thick-walled centrifuge tube. This mixture was centrifuged at $112000 \mathrm{~g}\left(\mathrm{r}_{\mathrm{av}}\right)$ in a fixed-angle rotor for $18 \mathrm{~h}$ at $17^{\circ}$ with the brake off. The white layer at the top of the liquid was carefully removed in two $0.7 \mathrm{ml}$ portions and transferred to an unused glass hydrolysis tube. An equal volume of isopropanol was added and the apolipoprotein $B$ allowed to precipitate overnight at $4^{\circ}$ (apolipoprotein $\mathrm{C}$ is soluble in the isopropanol mixture). After centrifugation at $1500 \mathrm{~g}$ for $30 \mathrm{~min}$ the supernatant fraction was carefully removed and the pellet subjected to three $8 \mathrm{ml}$ washes with isopropanol-water $(1: 1, \mathrm{v} / \mathrm{v})$. On rare occasions the apolipoprotein B dissolved during these washings but could be recovered by addition of $2 \mathrm{ml}$ isopropanol and leaving the mixture at $4^{\circ}$ for a few hours. The damp precipitate was then dried in vacuo and hydrolysed, after addition of $0.25 \mathrm{ml} 12 \mathrm{M}-\mathrm{HCl}$ (Aristar) and $0.25 \mathrm{ml}$ pure water, at $110^{\circ}$ for $18 \mathrm{~h}$. The solution was then transferred to a $1 \mathrm{ml}$ reactivial (V-vial) and dried under a stream of $\mathrm{N}_{2}$ before derivatization for GCMS analysis.

Certain precautions were found necessary to obtain good preparations. Relatively small amounts of VLDL were obtained compared with human plasma and thus even low contamination caused considerable problems. In the main study, larger amounts of plasma $(5 \mathrm{ml})$ were used rather than the 1-2 $\mathrm{ml}$ analysed in the preliminary study and which were based on procedures reported for studies on man. Transfer losses were minimized by performing all the later stages in the hydrolysis tube; this needed to be new as trace contaminations from previous hydrolysates proved troublesome, even after cleansing with chromic acid. Equally, the introduction of an electrophoresis step and excision of the appropriate band from the gel introduced sufficient AA contamination from the acrylamide and/or buffers (Patterson et al. 1991) to lower substantially the final enrichments obtained, as did the use of ion-exchange resins to desalt the protein hydrolysate (see also Cayol $e t$ al. 1995). Therefore, it was decided that the simpler preparation scheme, although occasionally yielding minor impurities, was the preferred option.

Plasma protein and albumin preparation. The total plasma protein fraction was obtained after precipitation with sulphosalicylic acid (SSA) to a final concentration of $80 \mathrm{~g} / 1$. The precipitate was washed three times with $8 \mathrm{ml} \mathrm{SSA}(80 \mathrm{~g} / \mathrm{l})$ and then dissolved in $0.3 \mathrm{M}-\mathrm{NaOH}$ at $37^{\circ}$ for $1 \mathrm{~h}$ and reprecipitated with SSA. The pellet was dissolved in $0.3 \mathrm{M}-$ $\mathrm{NaOH}$ before hydrolysis in $6 \mathrm{M}-\mathrm{HCl}$ as described earlier.

For albumin purification $0.5 \mathrm{ml}$ plasma was treated with $10 \mathrm{ml}$ cold TCA $(120 \mathrm{~g} / \mathrm{l})$ and the precipitate, collected by centrifugation, smoothed into a paste before dissolution in 10 $\mathrm{ml}$ absolute ethanol over $15 \mathrm{~min}$. The solution was clarified by centrifugation and the supernatant fraction dried under reduced pressure. The residue was then extracted into 0.3 $\mathrm{M}-\mathrm{NaOH}$ and acid-hydrolysed as described earlier.

In the preliminary experiment SDS-electrophoresis (Laemli, 1970) was used to assess the purity of isolated albumin (7\% gel) and apolipoprotein B100 (3.5\% gel).

Liver samples. Approximately 100-150 $\mathrm{mg}$ of the biopsy was homogenized in $2 \mathrm{ml}$ SSA $(80 \mathrm{~g} / \mathrm{l})$ and, after centrifugation, the supernatant fraction was removed for determination of free AA enrichments, as described subsequently. The protein pellet was 
washed three times with $2 \mathrm{ml} \mathrm{SSA}(80 \mathrm{~g} / \mathrm{l})$, then dissolved in $0.3 \mathrm{M}-\mathrm{NaOH}$ at $37^{\circ}$ for $1 \mathrm{~h}$ and reprecipitated with SSA, before acid hydrolysis as described earlier.

\section{Enrichment analyses}

Acidified urine $(1.5 \mathrm{ml})$ was passed through $1 \mathrm{ml}$ Dowex-50 $\left(\mathrm{H}^{+}, 100-200 \mathrm{mesh}, \times 8\right)$ to remove free glycine, and portions of the eluate $(0.02 \mathrm{ml}$ from fed animals and 0.4 from those fasted) were then reacted to yield the t-butyldimethylsilyl (tBDMS) derivative of hippurate. This was then analysed by electron impact GCMS, as described by Ballevre et al. (1990).

Plasma and blood free glycine, leucine and phenylalanine were converted to their tBDMS derivatives and the m-57 ions monitored while the oxo-acid of leucine, 4-methyl2-oxopentanoate (MOP), was measured as the quinoxalinol tBDMS derivative (Calder \& Smith, 1988). Liver homogenate free AA, and those obtained by acid hydrolysis of the apolipoprotein B100, were monitored as the heptafluorobutyryl n-butyl esters (HFB) under negative chemical ionization with $\mathrm{CH}_{4}$ as the reagent gas (MacKenzie \& Tenaschuk, 1979; Ford et al. 1985).

For plasma albumin and total protein only the amount of $\left[{ }^{2} \mathrm{H}_{5}\right]$ phenylalanine incorporation was monitored based on the enzymic conversion to phenylethylamine and measurement as the HFB derivative as described by Calder et al. (1992). At the same time the extent of labelling of $\left[{ }^{2} \mathrm{H}_{4}\right]$ tyrosine was quantified to yield information on compartmentalization between free phenylalanine and tyrosine pools.

\section{Calculations}

As described elsewhere (Lobley et al. 1996), estimates of ILR were obtained from rates of labelled AA infusion divided by the mean enrichments for the arterial plasma free AA during the final $6 \mathrm{~h}$ of infusion; corrections from $\mathrm{mmol} / \mathrm{h}$ to $\mathrm{g}$ protein $/ \mathrm{d}$ were based on the protein-bound AA content of sheep (MacRae et al. 1993).

In order to measure rates of tissue (or plasma) protein synthesis during continuous infusion experiments, the area under the enrichment-time curve is required. This is complicated by the recycling of isotope which occurs within the body, particularly from rapid turnover tissues such as gastrointestinal tract, lungs etc., which leads to "nonpseudoplateau' conditions. The area was calculated as the sum of two parts. The first describes the value for the first $6 \mathrm{~h}$ (when the first vascular samples were taken) and is based on a rate constant, $k$, of $24 / \mathrm{d}$ observed in other studies (results not shown):

$$
\text { area }=S_{\max }\left(k t+\mathrm{e}^{-k t}-1\right) / k \text {, }
$$

where $t$ is time (h), $\mathrm{S}_{\max }$ is enrichment of free AA at time $t$ and $k$ is the rate constant, which simplifies to $1 / \mathrm{h}$. The second part of the area, between $6 \mathrm{~h}$ and termination of infusion, was calculated as the sum of trapezoid analyses between each $2 \mathrm{~h}$ measurement point. Where appropriate this was extrapolated to include the interval between the last blood sample and the biopsy time (range 13-72 min). The areas for other precursors, e.g. based on free AA in hepatic liver homogenate, plasma or blood, were then estimated based on the assumption that these were in proportion to the ratio of free AA enrichments in that pool compared with arterial plasma.

The fractional rates of protein synthesis (FSR; as \% per d) for the liver protein were then calculated as:

$$
F S R=100 \times 24 \times\left(S_{B_{t}}-S_{B 0}\right) / \text { area, }
$$


where $S_{\mathrm{B} t}$ and $\mathrm{S}_{\mathrm{B} 0}$ are the protein-bound enrichments at times $t$ and zero respectively, with $S_{B 0}$ assumed to equal that of the plasma protein before the first infusion, and area is that of any selected precursor pool. This approach assumes no loss of label from the liver constitutive protein during the period of infusion.

For both plasma total protein and albumin the changes in enrichment with time between $6,8,10$ and $12 \mathrm{~h}$ were plotted as linear regressions and the slope then used, with the appropriate precursor area, to calculate FSR.

To estimate absolute rates of protein synthesis (ASR; g/d) certain assumptions were made. First, liver mass was taken as 0.0155 of animal live weight and contained $170 \mathrm{~g}$ protein $/ \mathrm{kg}$ (Lobley et al. 1994). Second, blood volume was set at 0.06 of live weight (Abbott et al. 1985) and plasma volume defined by packed cell volume. ASR was then obtained from FSR $\times$ protein mass.

\section{Statistics}

Data were first subjected to ANOVA to test whether order of treatment had an effect and for all comparisons this was shown not to be a significant factor, although with the small number of degrees of freedom this is not too surprising. Data were then compared by oneway ANOVA with animals treated as blocks and with intake as the treatment variable. This left a maximum of three residual degrees of freedom which again limited the chances of achieving statistical significance. Removing the animal factor increased the maximum residual degrees of freedom to six and data were also analysed in this fashion.

\section{RESULTS}

\section{General responses}

The surgical preparations used in the main preparation were prepared 7-11 months before this study and although all arterial and hepatic vein catheters remained patent, difficulties were encountered with the hepatic portal vein catheters in two of the sheep. For one of these animals alternative samples could be withdrawn from the mesenteric vein but there were marked differences in free AA enrichments compared with hepatic portal vein samples and for this reason data comparisons are presented for aortal and hepatic samples only. Several studies with such preparations have shown that isotopic dilution between hepatic portal and hepatic samples is small (e.g. Lobley et al. 1996) and unlikely to influence the general conclusions drawn concerning the precursor site for specific syntheses. For one sheep it proved impossible to obtain a biopsy sample during the fed phase.

\section{Purity of albumin and apolipoprotein B100 (Fig. 1)}

The simplified procedures adopted for isolation of both proteins yielded preparations of acceptable purity and the use of more refined techniques was considered to risk introduction of contaminant AA. In the majority of preparations examined by SDSelectrophoresis more than 0.9 of the material was restricted to one band of estimated molecular weight $520 \mathrm{kDa}$, but occasionally lower-molecular-weight material was present. For example, during the preliminary time-course experiment the apolipoprotein B100 fraction from one sheep contained such an impurity with a consequent lower enrichment relative to hepatic plasma free leucine compared with the other two animals $(0.59 v .0 .91)$. At this time only $2 \mathrm{ml}$ plasma was used for extraction and it was recognized that under these conditions impurities (from both plasma proteins and AA contamination of reagents 
(a)

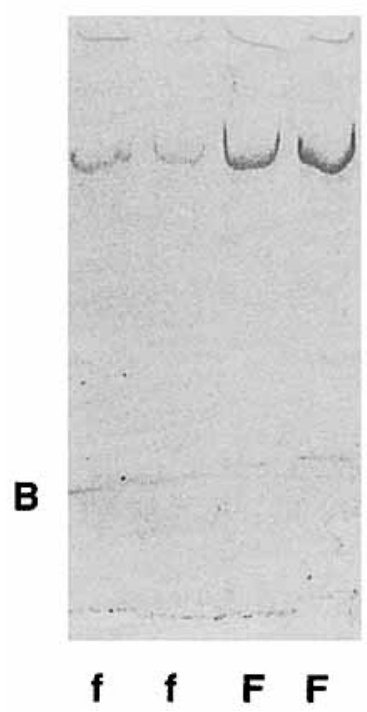

(b)

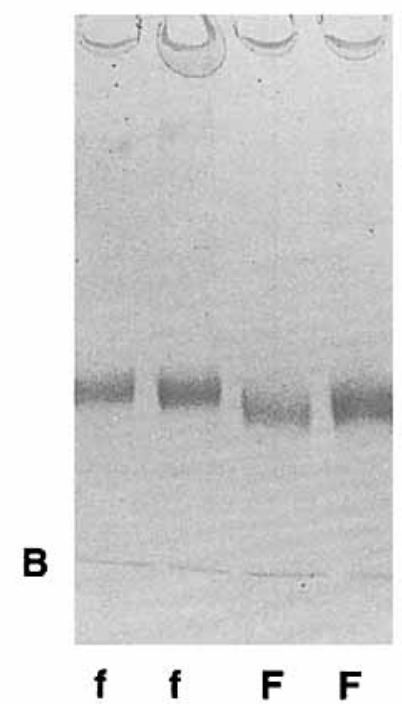

Fig. 1. (a). SDS-PAGE electrophoretogram of VLDL-apolipoprotein B100 (3.5\% gel). Samples represent 0.5 of extract from $5 \mathrm{ml}$ plasma from each of two fed $(\mathrm{F})$ and two fasted (f) sheep. (b). SDS-PAGE electrophoretogram of albumin $(7.5 \%$ gel). Samples were extracted from plasma from each of two fed (F) and two fasted (f) sheep. For both gels B represents the bromophenol blue dye front.

and glassware) could introduce considerable effects. Accordingly, extraction from a larger plasma sample $(5 \mathrm{ml})$ was employed for the main study. The albumin fraction was observed to be always at least $98 \%$ pure. For simplicity, the preparations will be described as albumin and apolipoprotein B100, but the possible presence of small amounts of impurities should not be forgotten in subsequent discussions.

Time course of apolipoprotein B100 synthesis (preliminary experiment; Fig. 2)

During the prolonged infusion of labelled leucine there was a small increase in plasma free AA enrichment, probably due to recycling of label. By 6-8 h of infusion the ratio of enrichments of apolipoprotein B100: arterial plasma free leucine was stabilized although the three sheep examined showed considerable differences in this ratio $(0.43,0.61$ and 0.63 ), associated with processing of too small a sample of plasma as outlined earlier. Thus, the time trends are probably correct but the mean absolute values may be lower than the true apolipoprotein B100 enrichment.

\section{Blood variables}

The packed cell volume was significantly greater during the fasted period $(0.346 v .0 .295$, SED $0.675, P=0.005)$ and the corresponding decrease in plasma volume was reflected in a non-significant increase in concentration of total protein $(68.0 v .65 .8 \mathrm{~g} / \mathrm{kg}$, SED 0.862 , $P=0.085$ ). Thus, the calculated amount of total plasma protein was slightly, but significantly, reduced $(150.7 v .145 .0 \mathrm{~g}$, SED $1.54, P=0.035)$, provided that the assumption of unchanged blood volume during the short-term nutritional changes is valid. The fasted 


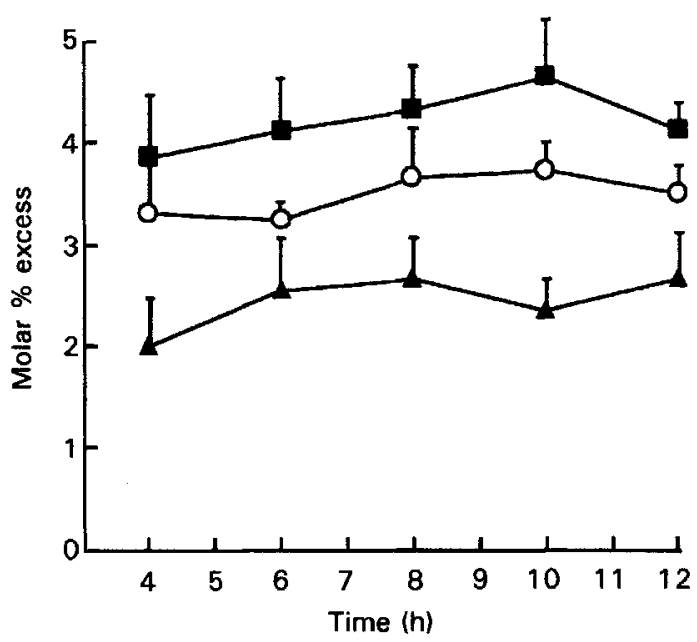

Fig. 2. Time course of enrichment changes in free leucine in arterial $(\mathbb{G})$ and hepatic portal venous $(O)$ plasma and in protein-bound leucine from VLDL-apolipoprotein B100 (A) during a $12 \mathrm{~h}$ continuous infusion of $\left[1-{ }^{13} \mathrm{C}\right]$ leucine. Values are means for three sheep, with standard deviations represented by vertical bars.

Table 1. Irreversible loss rates (ILR) and whole-body protein fluxes (WBPF) determined from simultaneous infusions of $\left[1-{ }^{13} \mathrm{C}\right]$ glycine, $\left[1-{ }^{13} \mathrm{C}\right]$ leucine and $\left[{ }^{2} \mathrm{H}_{5}\right.$-ring $]$ phenylalanine over $12 \mathrm{~h}$ in sheep either fasted for $3 \mathrm{~d}$ or fed $1200 \mathrm{~g}$ grass pellets/d*

(Mean values for four animals)

\begin{tabular}{|c|c|c|c|c|c|c|}
\hline & \multicolumn{3}{|c|}{$\mathrm{ILR} \uparrow(\mathrm{mmol} / \mathrm{h})$} & \multicolumn{3}{|c|}{ WBPF† (g/d) } \\
\hline & Glycine & Leucine & Phenylalanine & Glycine & Leucine & Phenylalanine \\
\hline Fed & 13.40 & 7.38 & 2.95 & 294 & 341 & 324 \\
\hline Fasted & 8.25 & $4 \cdot 11$ & 1.51 & 181 & 190 & 166 \\
\hline SED & 0.404 & 0.067 & 0.059 & 8.9 & 3.1 & 6.4 \\
\hline$P \ddagger$ & $<0.001$ & $<0.001$ & $<0.001$ & $<0.001$ & $<0.001$ & $<0.001$ \\
\hline
\end{tabular}

*For details of procedures see pp. 257-259.

†For details of calculations, see p. 259. The protein-bound contents $(\mathrm{g} / \mathrm{kg})$ of the three amino acids in total sheep wholebody protein were set at 82 (glycine), 68 (leucine) and 36 (phenylalanine).

\$For effect of intake, one-way ANOVA, three residual degrees of freedom (see p. 260).

phase resulted in a substantial reduction in both plasma albumin concentration $(24.5$ v. 29.3 $\mathrm{g} / \mathrm{kg}$, SED $0.69, P=0.006)$ and calculated total albumin content $(67.1$ v. $52.2 \mathrm{~g}$, SED 1.93, $P=0.004)$.

\section{Whole body amino acid fluxes (Table 1)}

Between 6 and $12 \mathrm{~h}$ of infusion the calculated fluxes, based on the plasma free AA enrichments, increased $2-3 \%$ per $h$ (results not shown), again presumably due to recycling of label from rapid turnover protein pools. Nutritional status caused significant changes $(P<0.001)$ in whole-body AA fluxes and this was also reflected in the values derived for minimum protein flux $(\mathrm{g} / \mathrm{d})$. The latter values were similar for all three AA but when the animals were fed the magnitude was always leucine $>$ phenylalanine $>$ glycine. 
Table 2. Fractional synthesis rates $(\times 100)$ of constitutive proteins in liver based on different precursor selections including free $\left[^{2} H_{5}\right.$ ]phenylalanine in arterial plasma $\left(k_{s p a}\right)$ or blood $\left(k_{s b a}\right)$, hepatic plasma $\left(k_{s p h}\right)$ or blood $\left(k_{s b h}\right)$ and liver homogenate $\left(k_{s h}\right)$ in sheep either fasted for $3 d$ or fed on $1200 \mathrm{~g}$ grass pellets/d*

(Mean values for four animals)

\begin{tabular}{|c|c|c|c|c|c|}
\hline & $\mathbf{k}_{\text {spa }} \dagger$ & $\mathbf{k}_{\mathrm{sba}} \dagger$ & $\mathbf{k}_{\mathrm{sph}} \dagger$ & $\mathbf{k}_{\text {sbb }} \dagger$ & $\mathbf{k}_{\mathbf{s h}} \dagger$ \\
\hline Fed & 9.1 & 9.9 & 12.9 & 13.4 & 15.5 \\
\hline Fasted & 9.6 & 11.0 & 12.4 & 13.4 & 18.8 \\
\hline SED $\ddagger$ & 1.74 & 2.01 & 1.88 & 2.46 & $5 \cdot 14$ \\
\hline$P \neq t$ & 0.783 & 0.627 & 0.822 & 0.978 & 0.569 \\
\hline
\end{tabular}

*For details of procedures, see pp. 257-259.

†For calculations see pp. 259-260.

\$For effect of intake, one-way ANOVA, three residual degrees of freedom (see p. 260); except for $\mathrm{k}_{\mathrm{sh}}$ where only two residual degrees of freedom due to one missing value for the fed state.

\section{Liver protein synthesis (Table 2)}

Liver protein synthesis was calculated in various ways, based on the enrichment of the protein fraction within the biopsy and a selection of free $\left[{ }^{2} \mathrm{H}_{5}\right]$ phenylalanine precursor pools, including arterial blood and plasma, hepatic vein blood and plasma and the liver homogenate. For no comparison was there any effect of intake although the absolute values calculated varied approximately twofold between selection of either arterial plasma or liver homogenate as precursor pool. The free $\left[{ }^{2} \mathrm{H}_{5}\right]$ phenylalanine enrichments from the liver homogenate were $0.51-0.59$ that of arterial plasma and $0.66-0.83$ that of hepatic (and hepatic portal) plasma, but were closer to those in blood and this is reflected in the corresponding FSR calculations.

For both phenylalanine and glycine the enrichments of the homogenate free pools were more similar (less diluted) to the plasma values in the fasted compared with the fed condition, e.g. for $\left[1-{ }^{13} \mathrm{C}\right]$ glycine enrichments the relative ratios of liver homogenate to arterial (or hepatic) plasma were $0.46(0.58) v .0 .64(0.74)$ between fed and fasted state. No intake-linked trend was observed for leucine (values $0.69(0.85)$ v. $0.68(0.85)$ respectively).

There was excellent concurrence between enrichments of liver free glycine and urinary hippurate in both the fed (2.80 (SE 0.12) v. 2.76 (SE 0.15)) and fasted (5.87 (SE 0.47) v. 5.80 $(\mathrm{SE} 0.20)$ ) condition, with an overall ratio of 1.02 (SE $0.026, n 7)$.

\section{Enrichment of apolipoprotein B100 (Table 3)}

The amount of apolipoprotein B100 fraction recovered was low and, in consequence, it was elected to devote all the sample to GCMS analysis. Thus, the purity of individual preparations could not be ascertained and, as discussed previously, small quantities of impurities can introduce problems. In two instances (out of eight infusions) the enrichment of one of the three samples of apolipoprotein B100 isolated was less than 0.95 of the other two. Based on the rationale that the presence of contaminant proteins would lower the enrichment these values were excluded, but to maintain a consistent approach the lowest enrichment from the other trios of samples was also excluded.

The apolipoprotein B100 enrichments were significantly less $(P<0.01)$ than those in arterial plasma for all three AA. Closer agreement was observed with arterial blood values, particularly during the fasted condition, although the differences were still significant $(P<0.01)$ when the sheep were fed. For both leucine and phenylalanine the protein-bound apolipoprotein B100 enrichments were similar to those in the hepatic venous plasma free 
Table 3. Ratio of enrichment (mol \% excess, mpe) of protein-bound amino acid in apolipoprotein $B 100$ (ApoB) to that of free amino acid $(A A)$ in either blood or plasma from the aorta or hepatic vein or from the liver homogenate for sheep either fasted for $3 \mathrm{~d}$ or fed $1200 \mathrm{~g}$ grass pellets/d*; data are also presented for comparison of Apo B enrichment with plasma 4-methyl-2-oxopentanoate (MOP)

(Mean values with their standard errors for four animals)

\begin{tabular}{|c|c|c|c|c|c|c|c|c|c|}
\hline \multirow[b]{2}{*}{ ApoB mpe:AA mpe } & & \multicolumn{2}{|c|}{ Glycine } & \multicolumn{2}{|c|}{ Leucine } & \multicolumn{2}{|c|}{ Phenylalanine } & \multicolumn{2}{|c|}{ MOP $\dagger$} \\
\hline & & Fed & Fasted & Fed & Fasted & Fed & Fasted & Fed & Fasted \\
\hline Arterial plasma AA & $\begin{array}{l}\text { Mean } \\
\text { SE }\end{array}$ & $\begin{array}{l}0.71 \\
0.02\end{array}$ & $\begin{array}{l}0.79 \\
0.04\end{array}$ & $\begin{array}{l}0.72 \\
0.06\end{array}$ & $\begin{array}{l}0.87 \\
0.03\end{array}$ & $\begin{array}{l}0.78 \\
0.11\end{array}$ & $\begin{array}{l}0.93 \\
0.04\end{array}$ & $\begin{array}{l}0.84 \\
0.08\end{array}$ & $\begin{array}{l}1.12 \\
0.04\end{array}$ \\
\hline Arterial blood AA & $\begin{array}{l}\text { Mean } \\
\text { SE }\end{array}$ & $\begin{array}{l}0.84 \\
0.02\end{array}$ & $\begin{array}{l}0.97 \\
0.05\end{array}$ & $\begin{array}{l}0.82 \\
0.07\end{array}$ & $\begin{array}{l}1.03 \\
0.05\end{array}$ & $\begin{array}{l}0.85 \\
0.10\end{array}$ & $\begin{array}{l}1.06 \\
0.05\end{array}$ & & \\
\hline Hepatic venous plasma AA & $\begin{array}{l}\text { Mean } \\
\text { SE }\end{array}$ & $\begin{array}{l}0.87 \\
0.03\end{array}$ & $\begin{array}{l}0.89 \\
0.03\end{array}$ & $\begin{array}{l}0.98 \\
0.08\end{array}$ & $\begin{array}{l}1.06 \\
0.02\end{array}$ & $\begin{array}{l}1.00 \\
0.05\end{array}$ & $\begin{array}{l}1.17 \\
0.01\end{array}$ & $\begin{array}{l}0.84 \\
0.08\end{array}$ & $\begin{array}{l}1.07 \\
0.04\end{array}$ \\
\hline Hepatic venous blood AA & $\begin{array}{l}\text { Mean } \\
\text { SE }\end{array}$ & $\begin{array}{l}1.02 t \\
0.04\end{array}$ & $\begin{array}{l}1.12 \\
0.04\end{array}$ & $\begin{array}{l}1.05 \ddagger \\
0.10\end{array}$ & $\begin{array}{l}1.21 \\
0.02\end{array}$ & $\begin{array}{l}0.98 \ddagger \\
0.05\end{array}$ & $\begin{array}{l}1.26 \\
0.02\end{array}$ & & \\
\hline Hepatic homogenate AA & $\begin{array}{l}\text { Mean } \\
\text { SE }\end{array}$ & $\begin{array}{l}1.39 \\
0.12\end{array}$ & $\begin{array}{l}1 \cdot 13 \\
0.10\end{array}$ & $\begin{array}{l}0.96 \\
0.16\end{array}$ & $\begin{array}{l}1.18 \\
0.09\end{array}$ & $\begin{array}{l}1.25 \\
0.35\end{array}$ & $\begin{array}{l}1.64 \\
0.02\end{array}$ & & \\
\hline
\end{tabular}

*For details of procedures, see pp. 256-259.

$\dagger$ In sheep there is no MOP in the erythrocyte so enrichments for plasma and blood are equal. $\ddagger$ For fed comparison only three animals.

Table 4. Fractional $(\times 100)$ and absolute $(\mathrm{g} / \mathrm{d})$ rates of protein synthesis of plasma total protein (Tot) and albumin (Alb) in sheep either fasted for $3 d$ or fed on $1200 \mathrm{~g}$ grass pellets $/ d^{*}$

(Mean values for four animals)

\begin{tabular}{|c|c|c|c|c|c|c|c|c|c|c|c|c|}
\hline & \multicolumn{6}{|c|}{ Fractional synthesis rate $\dagger$} & \multicolumn{6}{|c|}{ Absolute synthesis rate $\ddagger$} \\
\hline & \multicolumn{2}{|c|}{$\mathbf{k}_{\mathrm{sa}}$} & \multicolumn{2}{|c|}{$\mathrm{k}_{\mathrm{si}}$} & \multicolumn{2}{|c|}{$\mathbf{k}_{\mathrm{sh}}$} & \multicolumn{2}{|c|}{$\mathbf{A}_{\mathrm{sa}}$} & \multicolumn{2}{|c|}{$A_{\mathrm{si}}$} & \multicolumn{2}{|c|}{$A_{\text {sh }}$} \\
\hline & Tot & $\mathrm{Alb}$ & Tot & Alb & Tot & Alb & Tot & $\mathrm{Alb}$ & Tot & $\mathrm{Alb}$ & Tot & $\mathrm{Alb}$ \\
\hline Fed & 6.9 & 3.4 & 11.5 & 5.4 & 9.8 & 4.7 & 13.9 & 3.1 & 23.2 & 4.8 & 19.7 & 4.2 \\
\hline Fasted & 6.5 & 2.6 & 12.5 & $5 \cdot 2$ & 8.4 & 3.4 & $12 \cdot 6$ & 1.9 & $24 \cdot 2$ & 3.6 & $16 \cdot 2$ & 2.4 \\
\hline $\mathrm{SE}$ & 0.49 & 0.30 & 0.89 & 1.15 & 1.07 & 0.30 & 1.05 & 0.35 & 2.05 & 1.17 & $2 \cdot 31$ & 0.33 \\
\hline$P \S$ & 0.481 & 0.091 & 0.593 & 0.858 & 0.291 & 0.024 & 0.299 & 0.04 & 0.994 & 0.391 & 0.227 & 0.011 \\
\hline
\end{tabular}

*For details of procedures, see pp. 257-259.

† Values calculated assuming precursor enrichment is similar to that of free $\left[{ }^{2} \mathrm{H}_{5}\right]$ phenylalanine enrichment in arterial plasma $\left(k_{\mathrm{sa}}\right)$, liver homogenate $\left(\mathrm{k}_{\mathrm{si}}\right)$ or hepatic vein plasma $\left(\mathrm{k}_{\mathrm{sh}}\right)$.

$\ddagger$ Calculated from estimated protein pool size in plasma $\times$ fractional synthesis rates determined from assumed precursor enrichments as described.

§For the effect of intake, one-way ANOVA, three residual degrees of freedom (see p. 259), except for $k_{\mathrm{si}}$ values where only two residual degrees of freedom due to one missing value for the fed state.

AA at both nutritional levels, but slightly lower in the case of glycine for which the best agreement was obtained with hepatic venous blood. Apolipoprotein B100-bound AA enrichments exceeded those in the liver homogenate, except for leucine in the fed state, and these were significant for phenylalanine $(P<0.05)$ at both intakes and for glycine in the fed state. Plasma MOP enrichments were similar across all three sample sites (results not shown) and, in the fasted condition, were not significantly different from those of apolipoprotein B100-bound leucine, although they were significantly greater $(P<0.05)$ for the fed animals. 




Fig. 3. Temporal increase in enrichment of plasma albumin $(\square, O)$ and total protein $(\boldsymbol{\Delta}, \diamond)$ from sheep in the fasted $(\boldsymbol{\square}$, $\Delta)$ and fed $(\mathrm{O}$,$) condition during a 12 \mathrm{~h}$ continuous infusion of [ring ${ }^{2} \mathrm{H}_{5}$ ]phenylalanine. Values are means for four sheep, with standard deviations represented by vertical bars.

Synthesis of plasma total protein and albumin (Table 4)

Both total plasma protein and albumin showed linear incorporation of $\left[{ }^{2} \mathrm{H}_{5}\right]$ phenylalanine with $r^{2}$ values in excess of 0.98 between $6,8,10$ and $12 \mathrm{~h}$ of infusion (Fig. 3). The rates of protein synthesis again varied dependent on the choice of precursor pool but, in all cases, neither the FSR nor ASR of total plasma protein was influenced by nutritional state.

In contrast, use of any plasma (or blood)-based free $\left[{ }^{2} \mathrm{H}_{5}\right]$ phenylalanine enrichment gave a lower FSR for plasma albumin synthesis in the fasted condition and this difference was exacerbated when ASR was calculated. Values based on the enrichment of apolipoprotein B100 were similar to those calculated with hepatic vein plasma free $\left[{ }^{2} \mathrm{H}_{5}\right]$ phenylalanine (results not shown; see Table 3). No significant differences for intake were observed when the homogenate pool was selected as representative of the precursor enrichment.

If two extreme scenarios are adopted, namely that only albumin of the plasma proteins is synthesized in the liver or that all the plasma protein is of hepatic origin, then the respective contributions to total hepatic synthesis (constitutive plus appropriate export protein) were, for the fed and fasted conditions respectively, albumin $(0.17 v .0 .08$, SED $0.034, P<0.05)$ and total protein $(0.51 v .0 .38$, SED 0.105 , NS), when liver homogenate and hepatic venous free $\left[{ }^{2} \mathrm{H}_{5}\right]$ phenylalanine were chosen as representative of precursor enrichments of hepatic constitutive and export proteins respectively.

\section{DISCUSSION}

\section{Whole-body kinetics}

There is now a plethora of data which indicates that in both ruminants and non-ruminants whole-body protein flux is sensitive to nutritional state (e.g. Pell et al. 1986; Young et al. 1987; Harris et al. 1992). Values based on systemic infusions are confounded by removal and metabolism of absorbed AA by the splanchnic tissues, and the order of protein fluxes in the fed state (leucine $>$ phenylalanine $>$ glycine) is compatible with the proportion 
absorbed which is not extracted by the liver (see Lobley et al. 1995, 1996). Thus more leucine enters the post-hepatic circulation and this results in greater isotope dilution and a larger apparent systemic flux.

\section{Liver protein synthesis: general considerations}

Measurement of liver protein synthesis is confounded by two factors. The first relates to the contribution of export $v$. constitutive protein synthesis; during long-term continuous infusion procedures much of the synthesized export protein is secreted (with a lag-time of 30-40 min; e.g. Ballmer et al. 1995; Hunter et al. 1995) and not measured in the final liver sample. Not all the plasma proteins are of hepatic origin, however, and each must therefore be measured separately, both for fractional turnover and for pool size.

The second, and linked problem relates to the precursor pool for hepatic protein synthesis, which is probably neither single nor homogeneous. Proteins destined for export are probably synthesized on the rough endoplasmic reticulum and preferentially utilize AA as they enter the cell (Fern \& Garlick, 1976). In contrast, constitutive proteins are synthesized on polysomes within the cell cytosol and the precursor pool(s) would include cytosolic (intracellular) free AA or perhaps preferential use of AA released from protein degradation (e.g. Smith \& Sun, 1995). Such cellular compartmentalization is achieved, in part at least, by the selectivity conferred by the $3^{\prime}$ untranslated region of mRNA (Hesketh, 1994). The large-dose procedure has been used as a solution to some of the problems (e.g. Lobley et al. 1994; Tauveron et al. 1994; Ballmer et al. 1995; Hunter et al. 1995) but a range of criticisms has recently been levelled at this technique (cf. Garlick et al. 1989; Papet et al. 1992; Smith et al. 1992; Rennie et al. 1994; Smith \& Sun, 1995).

With the more traditional continuous infusion approach, a choice has to be made which of the accessible free AA pools, e.g. vascular inflow or outflow, tissue homogenate ('intracellular') etc., best represents the enrichment of the true precursor. For liver, access to splanchnic blood or tissue samples is often difficult. Consideration also needs to be given to whether the plasma or blood isotopic activity should be used, as these usually differ (Lobley et al. 1996).

Direct measurement of the true precursor, the aminoacyl-tRNA, is possible but this requires a tissue sample and has the accompanying concern that the turnover (charging and discharging) of the aminoacyl tRNA species is more rapid than extraction techniques (e.g. 0.3-3 s for rodent valyl-tRNA; Smith \& Sun, 1995). Furthermore, the values obtained represent only a mean value for the tissue and do not distinguish between different aminoacyl-tRNA pools which may support constitutive and export protein synthesis.

More specific approaches involve use of hippuric acid which is synthesized in the liver and rapidly eliminated from the body. This fast turnover allows urinary hippurate to reflect the hepatic intracellular enrichment of glycine, as has been confirmed in non-ruminants (e.g. Le Floc'h et al. 1995) and now in the sheep. There still remains the inherent assumption that all protein synthesis arises from intracellular compartments of similar glycine enrichment (Garfinkel \& Lajtha, 1963). Limited evidence would suggest that such as assumption would, at best, only cover synthesis of constitutive protein (Fern \& Garlick, 1976) and thus complementary approaches which examine export proteins are necessary to yield the overall picture. This requirement is fulfilled by apolipoprotein B100, which is synthesized predominantly in the liver and forms the core of serum lipoprotein complexes, including the small VLDL pool (Pownall \& Gotto, 1992; Blanco-Vaca et al. 1994), which has a half-life of less than $2 \mathrm{~h}$ in man (Kesaniemi et al. 1982; Reeds et al. 1992). Thus, the apolipoprotein B100 core of VLDL will, during a moderate length of infusion (greater than 
four half-lives), approach an asymptote for enrichment. This can then be compared with free AA enrichments in the various sampled pools or provide directly an estimate of precursor enrichment for other hepatic export proteins.

\section{Apolipoprotein B100 kinetics}

The ratios of enrichment of apolipoprotein B100: plasma free AA were stable within $6-8 \mathrm{~h}$ of infusion, although the calculated half-life (90-120 min) is probably much shorter when the time required to establish pseudoplateau conditions for the free AA is taken into account. Such short half-lives are not surprising when the small pool size in ruminants is considered, although whether the synthesis is specific to the liver requires confirmation.

For precursor identification the best overall match with apolipoprotein enrichments was observed for hepatic venous plasma. This can also be equated with hepatic portal plasma because in those situations where direct comparison could be made (all three preliminary sheep plus two on the nutritional trial) the ratio of free AA, enrichments of portal : hepatic-portal ranged from 1.02-1.06 for leucine (five sheep; seven infusions), 1.04-1.08 for glycine (two sheep, four infusions) and 1.00-1.12 for phenylalanine (two sheep, four infusions) and confirms earlier observations (Lobley et al. 1996). The mixed homogenate ('intracellular') free AA were obviously not representative of the precursor because these were of lower enrichment than the apolipoprotein fraction. These observations support the concept that export proteins can use preferentially AA from the (extra)vascular space (Fern \& Garlick, 1976).

As with human studies (Reeds et al. 1992) the ratio of enrichments in the apolipoprotein B100 extract: free AA in the arterial plasma rose during the fasted state but this was due to lower dilution of the hepatic portal venous plasma by unlabelled AA from dietary sources. Nutritional differences were also apparent in the enrichment matches of apolipoprotein B100-bound leucine and plasma MOP, regardless of sample site, in that good agreement was observed in the fasted condition, but marked differences appeared when the sheep were fed. Because plasma MOP is produced from various body sites (muscle, fat) in addition to liver such variation is not surprising and the closeness of match will depend on the overall contribution of the liver to whole-body flux of the oxo-acid. In sheep extra-hepatic synthesis probably contributes more than 0.5 of blood MOP (Harris et $a l .1992)$. The unsuitability of MOP as a general hepatic marker has also been shown in human subjects (Reeds et al. 1992).

\section{Albumin and total plasma protein synthesis}

Based on the use of hepatic venous plasma free AA enrichment (similar to that of apolipoprotein B100) to define the precursor for liver export protein synthesis then nutritional state altered albumin synthesis. Under fasting conditions both the fractional and calculated absolute synthesis rates based on the intravascular albumin pool were depressed by approximately 0.5 . These results support a range of earlier observations in nonruminants (e.g. Rothschild et al. 1968; Peters \& Peters, 1972; Yap \& Hafkenscheid, 1981; Hunter $e$ al. 1995) whereby albumin synthesis responds rapidly to nutrient supply.

The values reported here will be underestimated due to entry into the larger extravascular albumin pool (estimated in sheep as 1.5 -fold that of the intravascular pool; Abbot et al. 1985) by transcapillary exchange. The rate of exchange between compartments has been reported at $5 \%$ per $\mathrm{h}$ in healthy human subjects but can change substantially in response to disease or other challenges (Fleck et al. 1985). The average half-life of the albumin fraction in the fed condition (14.7 d) was similar to those obtained 
based on [ $\left.{ }^{125}\right] \mathrm{I}$-albumin kinetics (12.2-18.7 d; Abbot et al. 1985) but this was substantially increased $(20 \cdot 3 \mathrm{~d})$ in the fasted state.

The situation with total plasma protein is more confused. Albumin represents a lower proportion of plasma protein in fed ruminants than non-ruminants $(0.45 v .0 .60$; current study) and, because many of the other proteins are not synthesized within the liver, calculations based on hepatic precursors will be suspect. Interestingly, however, despite the decrease in albumin concentration during fasting the overall concentration of the remaining proteins increased. Thus, synthesis of these might be expected to be maintained or even increased and this was observed across a range of precursors used for calculation.

\section{Hepatic protein synthesis}

Based on the assumption that constitutive proteins are synthesized from the intracellular compartment then no significant changes in FSR were observed with alterations in nutrient supply. This supports earlier observations in sheep (Attaix et al. 1987; Lobley et al. 1994) and mature rats (Merry et al. 1987) but contrasts with other observations on laboratory rodents, where fasting reduced FSR (McNurlan et al. 1979; Preedy et al. 1988). The latter studies used the large dose technique in which the measurement period was only $10 \mathrm{~min}$ and would include labelled export protein which would not have completed cellular translocation, processing and secretion within the time-scale. Therefore, if albumin synthesis was depressed under the fasting condition this would have contributed to the overall reduced FSR. The question then becomes how much of the total synthesis is destined for export? The data from the current study indicate that the extremes are between 0.08 and 0.17 for albumin, with a trend towards a greater proportional output in the fed condition. Interestingly, and despite all the many species differences, similar proportions (0.16) have been reported for the overnight-fasted rat (Krahenbuhl et al. 1995). The current study does not provide information on the contribution (or nutritional sensitivity) of other hepatic export proteins but an upper limit can be set $(0.43)$ if all the plasma proteins are assumed to be of liver origin.

\section{CONCLUSIONS}

Of the two questions raised at the beginning of this study the answer to the first, concerning whether intake affects liver protein synthesis, is a qualified 'no' with regard to constitutive material and a probable 'yes' to albumin and perhaps other export proteins. These answers are confounded by lack of information on hepatic protein mass and plasma volume. If both decline during fasting then reductions in absolute synthesis $(\mathrm{g} / \mathrm{d})$ for both constitutive and export proteins during undernutrition are more probable. In contrast, the combined FSR are less sensitive to intake, 19 and $20 \%$ per $d$ for the fed and fasted conditions respectively, which agree well with the $22 \%$ per $d$ obtained by the large-dose procedure for sheep fed at 1.25 and 2.0 times maintenance (Lobley et al. 1994).

As to the second question, if albumin is considered to be the sole export protein from liver, and this were all available as an AA source to the peripheral tissues, less than $5 \mathrm{~g}$ would be provided on a daily basis. This is the equivalent of $0.8 \mathrm{~g} \mathrm{~N}$ but in practice the value may be somewhat higher because three of the essential AA (phenylalanine, lysine and histidine) for which a considerable proportion of that absorbed is extracted by the liver (Lobley et al. 1995) are present in relatively greater concentrations in albumin than in total ovine protein (MacRae et al. 1993). Thus, the albumin pool represents a putative enhanced 'store' for these AA and could therefore improve $\mathrm{N}$ retention by a maximum of 1.0-1.5 g/ d. This latter value depends, however, on two provisos; first, that peripheral tissues, in 
conjunction with blood peptidases, are able to use vascular protein as a source of free AA (Chalmers et al. 1982) and, second, that all albumin degradation occurs at extra-splanchnic sites. This latter requirement is almost certainly incorrect and, in which case, insufficient albumin is available to account for the discrepancy between post-hepatic provision of free amino acids and overall protein balance. Additional sources must therefore be sought.

The technical expertise of Miss M. Annand for measurement of total protein and albumin is gratefully recognized as is the contribution of $\mathrm{Mr} \mathbf{M}$. Phillippo who was responsible for the liver biopsies. This work was funded as part of the core budget to the Rowett Research Institute from the Scottish Office Agriculture, Environment and Fisheries Department.

\section{REFERENCES}

Abbott; E. M., Parkins, J. J. \& Holmes, P. H. (1985). Influence of dietary protein on the pathophysiology of ovine haemonchosis in Finn Dorset and Scottish Blackface lambs given a single moderate infection. Research in Veterinary Science 38, 54-60.

Attaix, D., Aurousseau, E., Bayle, G., Manghebati, A. \& Amal, M. (1987). Protein synthesis and degradation in growing lambs. In 5th International Symposium on Protein Metabolism and Nutrition, EAAP Publication no. 35, pp 24-27, Rostock, Germany: Wilhelm-Pieck University.

Ballevre, O., Cadenhead, A., Calder, A. G., Rees, W. D., Lobley, G. E., Fuller, M. F. \& Garlick P. J. (1990). Quantitative partition of threonine oxidation in pigs: effect of dietary threonine. American Journal of Physiology 259, E483-E491.

Ballmer, P. E., McNurlan, M. A., Essen, P., Anderson, S. E. \& Garlick, P. J. (1995). Albumin synthesis rates measured with $\left[{ }^{2} \mathrm{H}_{5}\right.$ ring]phenylalanine are not responsive to short-term intravenous nutrients in healthy humans. Journal of Nutrition 125, 512-519.

Blanco-Vaca, F., Gaubatz, J. W., Bren, N., Kottke, B. A., Morrisett, J. D. \& Guevara J. Jr (1994). Indentification and quantification of apolipoproteins in addition to apo [a] and apo b-100 in human lipoprotein [a]. Chemistry and Physics of Lipids 67/68, 35-42.

Burrin, D. G., Ferrell, C. L., Britton, R. A. \& Bauer, M. (1990). Level of nutrition and visceral organ size and metabolic activity in sheep. British Journal of Nutrition 64, 439-448.

Calder, A. G., Anderson, S. E., Grant, I., McNurlan, M. A. \& Garlick, P. J. (1992). The determination of low d $5-$ phenylalanine enrichment (0.002-0.09 Atom Percent Excess) after conversion to phenylethylamine, in relation to protein turnover studies by gas chromatography (electron ionisation) mass spectrometry. Rapid Communications in Mass Spectrometry 6, 421-424.

Calder, A. G. \& Smith, A. (1988). Stable isotope ratio analysis of leucine and ketoisocaproic acid in blood plasma by gas chromatography/mass spectrometry. Rapid Communications in Mass Spectrometry 2, 14-16.

Cayol, M., Capitan, P., Prugnaud, J., Genest, M., Beaufrere, B \& Obled, C. (1995). Cation-exchange resins release amino acids: consequences for tracer studies. Analytical Biochemistry 227, 392-394.

Chalmers, M. I., Grant, I. \& White, F. (1982). Free amino-nitrogen exchange across the hindquarters of fed and fasted sheep and pigs. Joumal of Agricultural Science, Cambridge 99, 91-104.

Elwyn, D. M., Parikk, H. C. \& Shoemaker, W. C. (1968). Amino acid movements between gut, liver and periphery in unanaesthetized dog. American Journal of Physiology 215, 1260-1275.

Fern, E. B. \& Garlick, P. J. (1976). Compartmentation of albumin and ferritin synthesis in rat liver in vivo. Biochemical Journal 156, 189-192.

Fleck, A., Raines, G., Hawker, F., Trotter, J., Wallace, P. I., Ledingham, I. McA. \& Calman, K. C. (1985). Increased vascular permeability: a major cause of hypoalbuminaemia in disease and injury. Lancet $1,781-$ 784.

Ford, G. D., Cheng, K. N. \& Halliday, D. (1985). Analysis of $\left[1-{ }^{13} \mathrm{C}\right]$ leucine and $\left[{ }^{13} \mathrm{C}\right] \mathrm{KIC}$ in plasma by capillary gas chromatography/mass spectrometry in protein turnover studies. Biomedical Mass Spectrometry $12,432-436$.

Garfinkel, D. \& Lajtha, A. (1963). A metabolic inhomogeneity of glycine in vivo. 1. Experimental determination. Journal of Biological Chemistry 238, 2429-2439.

Garlick, P. J., McNurlan, M. A., Essen, P. \& Wernerman, J. (1994). Measurement of tissue protein synthesis rates in vivo: a critical analysis of contrasting methods. American Journal of Physiology 266, 287-297.

Gornall, A. G., Bardawill, C. J. \& David, M. M. (1949). Determination of serum proteins by means of the biuret reaction. Journal of Biological Chemistry 177, 751-766.

Harris, P. M., Lobley, G. E., Skene, P. A., Buchan, V., Calder, A. G., Anderson, S. E. \& Connell, A. (1992). Effect of food intake on hind-limb and whole-body protein metabolism in young growing sheep: chronic studies based on arterio-venous techniques. British Journal of Nutrition 68, 388-407. 
Haythorn, P. \& Sheehan, M. (1979). Improved centrifugal analyzer assay of albumin. Clinical Chemistry 25, 194.

Heitmann, R. N. \& Bergman, E. N. (1980). Transport of amino acids in whole blood and plasma of sheep. American Journal of Physiology 239, E242-E247.

Hesketh, J. (1994). Translation and the cytoskeleton: a mechanism for targeted protein synthesis. Molecular Biology Reports 19, 233-243.

Hunter, K. A., Ballmer, P. E. Anderson, S. E., Broom, J., Garlick, P. J. \& McNurlan, M. A. (1995). Acute stimulation of albumin synthesis rate with oral meal feeding in healthy subjects measured with [ring- ${ }^{2} \mathrm{H}_{5}$ ]phenylalanine. Clinical Science 88, 235-242.

Kesaniemi, Y. A., Vega, G. L. \& Grundy, S. M. (1982). Kinetics of apolipoprotein B in normal and hyperlipidemic man: review of current data. In Lipoprotein Kinetics and Modelling, pp. 181-205 [M. Berman, S. M. Grundy and B. V. Howard, editors]. New York: Academic Press.

Krahenbuhl, S., Marti, U., Grant, I., Garlick, P. J. \& Ballmer, P. E. (1995). Characterization of mechanisms causing hypoalbuminaemia in rats with long-term bile duct ligation. Journal of Hepatology 23, 79-86.

Laemli, U.K. (1970). Cleavage of structural proteins during the assembly of the head of bacteriophage T4. Nature 227, 680-685.

Le Floc'h, N., Obled, C. \& Seve, B. (1995). In vivo threonine oxidation rate is dependent on threonine dietary supply in growing pigs fed low to adequate levels. Journal of Nutrition 125, 2550-2562.

Lobley, G. E., Connell, A., Lomax, M. A., Brown, D. S., Milne, E., Calder, A. G. \& Famingham, D. A. H. (1995). Hepatic detoxification of ammonia in the ovine liver: possible consequences for amino acid catabolism. British Journal of Nutrition 73, 667-685.

Lobley, G. E., Connell, A., Milne, E., Newman, A. M. \& Ewing, T. A. (1994). Protein synthesis in splanchnic tissues of sheep offered two levels of intake. British Journal of Nutrition 71, 3-12.

Lobley, G. E., Connell, A., Revell, D. K., Brown, D. S. \& Calder, A. G. (1996). Splanchnic-bed transfers of amino acids in sheep blood and plasma, as monitored through use of a multiple U- ${ }^{13} \mathrm{C}-$ labelled amino acid mixture. British Journal of Nutrition 75, 217-235.

MacKenzie, S. L. \& Tenaschuk, D. (1979). Quantitative formation of N(O,S)-heptafluorobutyryl isobutyl amino acids for gas chromatographic analysis. II. Acylation. Journal of Chromatography 173, 54-63.

McNurlan, M. A., Tomkins, A. M. \& Garlick, P. J. (1979). The effect of starvation on the rate of protein synthesis in rat liver and small intestine. Biochemical Journal 178, 373-379.

MacRae, J. C., Walker, A., Brown, D. \& Lobley, G. E. (1993). Accretion of total protein and individual amino acids by organs and tissues of growing lambs and the ability of nitrogen balance techniques to quantitate protein retention. Animal Production 57, 237-245.

Merry, B. J., Holehan, A. M., Lewis, S. E. M. \& Goldspink, D. F. (1987). The effects of ageing and chronic dietary restriction on in vivo hepatic protein synthesis in the rat. Mechanisms of Ageing and Development 39 , 189-199.

Milano, G. D. (1994). Consequences of ammonia metabolism across splanchnic tissues in fasted sheep. MSc Thesis, University of Aberdeen.

Mortimore, G. E. \& Surmacz, C. A. (1984). Liver perfusion: an in vitro technique for the study of intracellular protein turnover and its regulation in vivo. Proceedings of the Nutrition Society 43, 161-167.

Motil, K. J., Opekun, A. R., Montandon, C. M., Berhold, H. K., Davis, T. A., Klein, P. D. \& Reeds, P. J. (1994). Leucine oxidation changes rapidly after dietary protein intake is altered in adult women but lysine flux is unchanged as is lysine incorporation into VLDL-apolipoprotein B-100. Journal of Nutrition 124, 41-51.

Papet, I., Glomot, F., Grizard, J. \& Amal, M. (1992). Leucine excess under conditions of low or compensated aminoacidemia does not change skeletal muscle and whole body protein synthesis in suckling lambs during postprandial period. Journal of Nutrition 122, 2307-2315.

Patterson, B. W., Hachey, D. L., Cook, G. I., Amann, J. M. \& Klein, P. D. (1991). Incorporation of a stable isotopically labelled amino acid into multiple human apolipoproteins. Journal of Lipid Research 32, 10631072.

Pell, J. M., Calderone, E. M. \& Bergman, E. N. (1986). Leucine and $\alpha$-ketoisocaproate metabolism and interconversions in fed and fasted sheep. Metabolism 35, 1005-1016.

Peters, T. P. \& Peters, J. C. (1972). The biosynthesis of rat serum albumin. VI. Intracellular transport of albumin and rates of albumin and liver protein synthesis in vivo under various physiological conditions. Journal of Biological Chemistry 247, 3858-3863.

Pinnel, A. E. \& Northam, B. E. (1978). New automated dye-binding method for serum albumin determination with bromocresol purple. Clinical Chemistry 24, 80-86.

Pownall, M. J. \& Gotto, A. M. (1992). Lipid metabolism and the plasma lipoproteins. In The Heart and the Cardiovascular System, 2nd ed., pp. 197-205 [H. A. Fozzard, E. Haber, R. B. Jennings, A. M. Katz and H. E. Morgan, editors]. New York: Raven.

Preedy, V. R., Paska, L., Sugden, P.H. Schofield, P.S. \& Sugden, M.C. (1988). The effects of surgical stress and short-term fasting on protein synthesis in vivo in diverse tissues of the mature rat. Biochemical Journal 250 , 179-188. 
Reeds, P. J., Hachey, D. L., Patterson, B. W., Motil, K. J. \& Klein, P. D. (1992). VLDL apolipoprotein B-100, a potential indicator of the isotopic labelling of the hepatic protein synthetic precursor pool in humans: studies with multiple stable isotopically labelled amino acids. Journal of Nutrition 122, 475-466.

Rennie, M. J., Smith, K. \& Watt, P. W. (1994). Measurement of human tissue protein synthesis: an optimal approach. American Journal of Physiology 266, E298-E307.

Rérat, A., Simoes-Nuñes, C., Mendy, F., Vaissade, P. \& Vaugelade, P. (1992). Splanchnic fluxes of amino acids after duodenal infusion of carbohydrate solutions containing free amino acids or oligopeptides in the nonanaesthetized pig. British Journal of Nutrition 68, 111-138.

Reynolds, C. K., Tyrrell, H. F. \& Reynolds, P. J. (1991). Effects of diet forage- to-concentrate ratio and intake on energy metabolism in growing beef heifers: net nutrient metabolism by visceral tissues. Journal of Nutrition 121, 1004-1015.

Rothschild, M. A., Oratz, M., Mongelli, J. \& Schreiber, S. S. (1968). Effects of a short-term fast on albumin synthesis studied in vivo in the perfused liver and on amino acid incorporation by hepatic microsomes. Journal of Clinical Investigation 47, 2591-2599.

Schirmer, M. D. \& Harper, A. E. (1970). Adaptive response of mammalian histidine-degrading enzymes. Journal of Biological Chemistry 245, 1204-1211.

Smith, C. B. \& Sun, Y. (1995). Influence of valine flooding on channelling of valine into tissue pools and on protein synthesis. American Journal of Physiology 268, E735-E744.

Smith, K., Barua. J. M., Watt, P. W., Scrimgeour, C. M. \& Rennie, M. (1992). Flooding with L-[1- ${ }^{13}$ C $]$ leucine stimulates human muscle protein incorporation of continuously infused $L-\left[1-{ }^{13} \mathrm{C}\right]$ valine. American Journal of Physiology 266, E372-E376.

Tauveron, I., Larbaud, D., Champredon, C., Debras, E., Tesseraud, S., Bayle, G., Bonnet, Y., Thieblot, P. \& Grizard, J. (1994). Effect of hyperinsulinemia and hyperaminoacidemia on muscle and liver protein synthesis in lactating goats. American Journal of Physiology 267, E877-E885.

Yap, S. J. \& Hafkenscheid, J. C. M. (1981). Effect of starvation on the synthesis rate of albumin in vivo and its relation to the concentrations of amino acids in the peripheral blood, the portal circulation and in the liver cytosolic fraction. Annals of Nutrition and Metabolism 25, 158-164.

Young, V. R., Gucalp, C., Rand, W. M., Matthews, D. E. \& Bier, D. M. (1987). Leucine kinetics during three weeks at submaintenance-to-maintenance intakes of leucine in man: adaptation and accommodation. Human Nutrition: Clinical Nutrition 41C, 1-18. 